\title{
Physiological and biochemical changes in 'Fuyu' persimmon buds during dormancy
}

\author{
Gabriely Pinto Pereira ${ }^{1}$ (i) Felipe Francisco ${ }^{1}$ (i) Aline José Maia ${ }^{2}$ (i) Renato Vasconcelos Botelho $^{2}$ (i) \\ Luiz Antonio Biasi ${ }^{*}$ (i) Ruy Inacio Neiva de Carvalho ${ }^{3}$ (D) Flávio Zanette $^{1}$ (D)
}

${ }^{1}$ Programa de Pós-graduação em Agronomia, Produção Vegetal, Universidade Federal do Paraná (UFPR), 80035-050, Curitiba, PR, Brasil. E-mail: biasi@ufpr.br. "Corresponding author.

${ }^{2}$ Departamento de Agronomia, Universidade Estadual do Centro-Oeste (UNICENTRO), Guarapuava, PR, Brasil.

${ }^{3}$ Escola de Ciências da Vida, Pontifícia Universidade Católica do Paraná, Curitiba, PR, Brasil.

ABSTRACT: This study identified physiological and biochemical changes in 'Fuyu' persimmon buds during dormancy. Branches were collected between March and August 2015. Dormancy was evaluated by biological testing of isolated node cuttings at $25{ }^{\circ} \mathrm{C}$ and a photoperiod of $16 \mathrm{~h}$. The variables analyzed were water content; reducing sugar content; respiratory activity; activity of superoxide dismutase (SOD), catalase (CAT), ascorbate peroxidase (APX), guaiacol peroxidase (POD) and polyphenol oxidase (PPO) enzymes; hydrogen peroxide content $\left(\mathrm{H}_{2} \mathrm{O}_{2}\right)$ and lipid peroxidation. At the end of March 2015, the plants were already dormant, and the leaves and fruits present indicated a paradormancy effect. Induction of endodormancy may have occurred in June 2015, when chilling hours (CH) below $7.2{ }^{\circ} \mathrm{C}$ and higher $\mathrm{CH}$ below $12^{\circ} \mathrm{C}$ began to accumulate, which coincided with the period in which there was a decrease in water content and respiratory activity, an increase in reducing sugars, a decrease in $\mathrm{SOD}, \mathrm{CAT}, \mathrm{APX}$ and $\mathrm{PPO}$ and an increase in $\mathrm{H}_{2} \mathrm{O}_{2}$. After an accumulation of $553 \mathrm{CH}$ below $12{ }^{\circ} \mathrm{C}$, the budburst capacity increased, and the buds presented increased water content, decreased reducing sugars content, increased respiratory activity, low activity in SOD, CAT, APX and POD and high levels of $\mathrm{H}_{2} \mathrm{O}_{2}$.

Key words: Diospyros kaki, budburst, oxidative stress, reactive oxygen species.

Alterações fisiológicas e bioquímicas em gemas de caquizeiro 'Fuyu' durante a dormência

RESUMO: O objetivo deste trabalho foi identificar alterações fisiológicas e bioquimicas em gemas de caquizeiro 'Fuyu'durante a dormência. Ramos foram coletados entre março e agosto de 2015. A dormência foi avaliada pelo teste biológico de estacas de nós isolados, a $25{ }^{\circ} \mathrm{C} e$ fotoperiodo de $16 \mathrm{~h}$. As variáveis analisadas foram umidade ponderal, teor de açúcares solúveis, atividade respiratória, atividade das enzimas superóxido dismutase (SOD), catalase (CAT), ascorbato peroxidase (APX), guaiacol peroxidase (POD) e polifenoloxidase (PPO), teor de peróxido de hidrogênio $\left(\mathrm{H}_{2} \mathrm{O}_{2}\right)$ e peroxidação lipídica. No final de março de 2015 as plantas já estavam dormentes, as folhas e frutos presentes indicam efeito de paradormência. A indução da endodormência pode ter ocorrido em junho de 2015, quando iniciou acúmulo de horas de frio (HF) abaixo de $7,2{ }^{\circ} \mathrm{C}$ e maiores $H F$ abaixo de $12{ }^{\circ} \mathrm{C}$, que coincidiu com o periodo que houve diminuição da umidade e da atividade respiratória, aumento dos açúcares redutores, diminuição da atividade da SOD, CAT, APX e PPO e aumento de $\mathrm{H}_{2} \mathrm{O}_{2}$. Após acúmulo de 553 $H F$ abaixo de $12{ }^{\circ} \mathrm{C}$, a capacidade de brotação aumentou e as gemas apresentaram aumento da umidade, diminuição do teor de açúcares redutores, aumento da atividade respiratória, baixa atividade da SOD, CAT, APX e POD e elevados teores de $\mathrm{H}_{2} \mathrm{O}_{2}$.

Palavras-chave: Diospyros kaki, brotação, estresse oxidativo, espécies reativas de oxigênio.

\section{INTRODUCTION}

Persimmon (Diospyros kaki L.) is a fruit tree of subtropical climates originating in China that presents bud dormancy in autumn and winter (GUAN et al., 2019). Bud dormancy is an adaptive mechanism of plants that makes it possible to survive in adverse climatic conditions and it is based on the temporary suspension of visible growth; although, essential metabolic activities continue to occur (FALAVIGNA et al., 2019).

Bud dormancy comprises the stages of paradormancy, in which budburst is inhibited by the influence of other plant structures on the bud; endodormancy, when endogenous bud factors inhibit budburst; and ecodormancy, in which unfavorable environmental factors limit budburst. To start a new vegetative cycle under natural conditions, plants

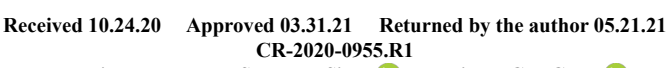


need to be exposed to periods of low temperatures (FALAVIGNA et al., 2019).

The events that occur from the initiation to the release of endodormancy are still not entirely clear. The dynamics of dormancy involve external factors, such as temperature and photoperiod (FALAVIGNA et al., 2019), and internal factors, such as the balance of promoters and growth inhibitors (ZHENG et al., 2015), protein and carbohydrate metabolism (RADY \& EL-YAZAL, 2013), water content (MARAFON et al., 2011; SCHMITZ et al., 2015), mitochondrial respiration and antioxidative metabolism (BEAUVIEUX et al., 2018).

During dormancy, water migrates from the buds to tissues less sensitive to cold such as the cataphylls of the buds and adjacent tissues of the branch. This dehydration protects the bud meristematic tissues from the damages caused by low temperatures (YOOYONGWECH et al., 2008). After the release of dormancy, the increase in bud water content influences metabolic activity (ARORA et al., 2003). Bud water content may be a physiological indicator of the level of metabolic activity of the cells and the growth potential of the buds even before the first morphological signs of budburst occur (MARAFON et al., 2011).

The stress caused by low temperatures and the decrease in respiratory activity in the winter period induces an increase in the production of reactive oxygen species (ROS), such as superoxide $\left(\mathrm{O}_{2}^{-}\right)$and hydrogen peroxide $\left(\mathrm{H}_{2} \mathrm{O}_{2}\right)$, which in high concentrations may be toxic to plants and cause oxidative stresses such as lipid peroxidation (VERGARA et al., 2012; BEAUVIEUX et al., 2018).

Changes in bud hydration associated with respiratory, carbohydrate metabolism and oxidative stress may be part of the mechanism of induction and release of dormancy (BEAUVIEUX et al., 2018). In persimmon tree; however, little is known about the involvement of these biochemical mechanisms in dormancy dynamics. Knowledge of the physiological and biochemical alterations that occur in dormant buds of persimmon can help to understand the bud dormancy of this species and to support future studies.

The objective of this study was to identify the physiological and biochemical changes in 'Fuyu' persimmon buds during dormancy.

\section{MATERIALS AND METHODS}

One-year-old, 30 to $40 \mathrm{~cm}$ long branches of 'Fuyu' persimmon tree were collected on 10 dates every 14 days, from March 31 to August 4, 2015.
These samplings were always performed between 9 and 11 a.m. from 19-year-old plants in a commercial orchard located in Campina Grande do Sul, Parana State, Brazil $\left(25^{\circ} 18^{\prime} \mathrm{S}, 49^{\circ} 03^{\prime} \mathrm{W}\right.$ and at an average height of $918 \mathrm{~m}$ ).

The climate of the municipality, according to the classification of Köeppen, is of the type Cfb-subtropical moist mesothermic. To evaluate the natural occurrence of chilling, the number of chilling hours below or equal to $7.2^{\circ} \mathrm{C}$ and $12{ }^{\circ} \mathrm{C}$ was measured, based on the climate data provided by Simepar (Meteorological System of Paraná).

\section{Bud dormancy}

Bud dormancy was studied through biological testing of isolated node cuttings in a growth room at $25^{\circ} \mathrm{C}$ and with photoperiod of $16 \mathrm{~h}$. The upper half of the branches was divided into $6 \mathrm{~cm}$ long cuttings, keeping only the upper lateral vegetative bud.

The cuttings were kept in plastic vases using moistened vermiculite as substrate, covered with transparent polyethylene bags to maintain humidity and it evaluated individually every two days for a period of up to 40 days after the experiment was initiated, according to the international $\mathrm{BBCH}$ scale for the parameter "Green Tip" (GT) (BBCH 07-Beginning of bud burst: first green leaf tips just visible) (GARCÍA-CARBONELL et al., 2002).

Based on this parameter, the average budburst time (ABT), which represents the average number of days spent between the start of the experiment and GT stage detection, and the final budburst rate (FBR), which represents the percentage of cuttings with buds that achieved GT, were calculated.

\section{Water content of buds}

The water content (WC) was calculated by using the equation: $\mathrm{WC}=(\mathrm{FM}-\mathrm{DM}) / \mathrm{DM}$, where $\mathrm{FM}$ and DM are the fresh and the dry mass $(\mathrm{g})$, respectively (MARAFON et al., 2011). Samples of $0.5 \mathrm{~g}$ of lateral vegetative buds were collected from the upper half of the branches and weighed in an analytical balance to obtain the FM. The buds were kept at $65^{\circ} \mathrm{C}$ under forced ventilation until they reached constant mass to record the DM.

\section{Respiratory activity of buds}

Bud respiratory activity was analyzed using the tetrazolium test. The lateral vegetative buds of the upper half of the branches were collected and it was divided longitudinally in order to expose their internal tissues. Buds samples were maintained in $5 \mathrm{~mL}$ of $1 \%$ 
(w/v) 2,3,5-triphenyl-tetrazolium chloride solution in sealed vials and held at $25^{\circ} \mathrm{C}$ for $2 \mathrm{~h}$. The buds were then removed from this solution and maintained in $6 \mathrm{~mL}$ of absolute ethyl alcohol (PA) at room temperature for $1 \mathrm{~h}$. Color intensity obtained in the ethyl alcohol solution was measured by absorbance spectrophotometry at $560 \mathrm{~nm}$. To remove the effect of bud moisture on the interpretation of the results, the absorbance value obtained was corrected for absorbance per $100 \mathrm{mg}$ of dry mass of buds (CARVALHO et al., 2010b).

\section{Reducing sugar content}

Reducing sugars were quantified by the method of LEVER (1972).

\section{Protein content}

The determination of protein content was performed according to BRADFORD (1976).

\section{Oxidative stress in buds}

To obtain enzymatic extract, $0.13 \mathrm{~g}$ of buds was macerated in a mortar in liquid nitrogen. The macerated buds were transferred to precooled falcon tubes, where $2 \mathrm{~mL}$ of $50 \mathrm{mM}$ potassium phosphate buffer ( $\mathrm{pH}$ 7.0) containing $0.1 \mathrm{mM}$ EDTA and 1\% (w/w) PVP (polyvinylpyrrolidone) was added. The homogenate was centrifuged at $5,000 \mathrm{rpm}$ for $30 \mathrm{~min}$ at $4{ }^{\circ} \mathrm{C}$, and the supernatant obtained was collected, considered as an enzyme extract, and then stored in a freezer at $-20{ }^{\circ} \mathrm{C}$ for further determination of enzymatic activity (KAR \& MISHRA, 1976).

Superoxide dismutase activity (SOD, EC 1.15.1.1) activity was evaluated as proposed by GIANNOPOLITIS \& RIES (1977), with some modifications, by means of the enzymatic capacity of nitro blue tetrazolium (NBT) photoreduction inhibition. Catalase activity (CAT, EC 1.11.1.6) activity was quantified by the method of GÓTH (1991) modified by TOMÁNKOVÁ et al. (2006) through a stable complex formed by ammonium molybdate with hydrogen peroxide.

Guaiacol peroxidase activity (POD, EC 1.11.1.7) activity was determined according to LUSSO \& PASCHOLATI (1999) by measuring the conversion of guaiacol to tetraguaiacol. Ascorbate peroxidase activity (APX, EC 1.11.1.11) activity was determined according to the method adapted from NAKANO \& ASADA (1981). Polyphenol oxidase activity (PPO, EC 1.10.3.1) activity was determined according to the methodology proposed by DUANGMAL \& APENTEN (1999). Hydrogen peroxide content $\left(\mathrm{H}_{2} \mathrm{O}_{2}\right)$ was determined according to the methodology described by LORETO \& VELIKOVA (2001), with some modifications. Lipid peroxidation was evaluated according to a methodology proposed by VELIKOVA et al. (2000).

\section{Statistical analysis}

The experimental design was completely randomized with 10 treatments (collection dates) and four replicates with 10 cuttings per plot for the biological test and five replicates for the other variables. Variances of the treatments were tested for homogeneity by Bartlett's test. The means of the treatments with significant differences as determined by an $\mathrm{F}$ test in the analysis of variance were submitted to the regression analysis. Correlation calculations, using Pearson's coefficient, were performed for the temperature, chilling hours, dormancy and biochemical parameters.

\section{RESULTS AND DISCUSSION}

There was a high fluctuation in the daily temperature during the period of persimmon tree dormancy, from late March to early August 2015 (Figure 1). The number of chilling hours below $7.2^{\circ} \mathrm{C}$ that occurred until the last collection of branches, on August 04, was only $27 \mathrm{CH}$ (Table 1); it was below the cold requirement for releasing dormancy of 'Fuyu' persimmon, which is $504 \mathrm{CH}$ below $7.2{ }^{\circ} \mathrm{C}$ (FAQUIM et al., 2007).

\section{Bud dormancy}

At the beginning of the experiment, the buds already had strong inhibition of growth. The high ABT of 32.22 days and the low FBR of $26.67 \%$ on $03 / 31$ (Figure 2) indicated that the plant was in bud dormancy (EL YAACOUBI et al., 2016). This response may have been obtained by the initiation of endodormancy but may also be related to the effect of paradormancy, due to the presence of leaves and fruits on the plants.

Paradormancy refers to the influence of other plant structures on the bud and ceases when the factor causing the inhibition, such as the leaves that can compete with the buds for water and nutrients, is eliminated (LANG et al., 1987). However, even after fruit harvest and leaf fall at the end of April, the ABT remained high, with values higher than 30 days until 07/07, and the FBR was low, although oscillations with significant differences were observed for the number of budburst in the period. At this time, there may have been a greater influence 


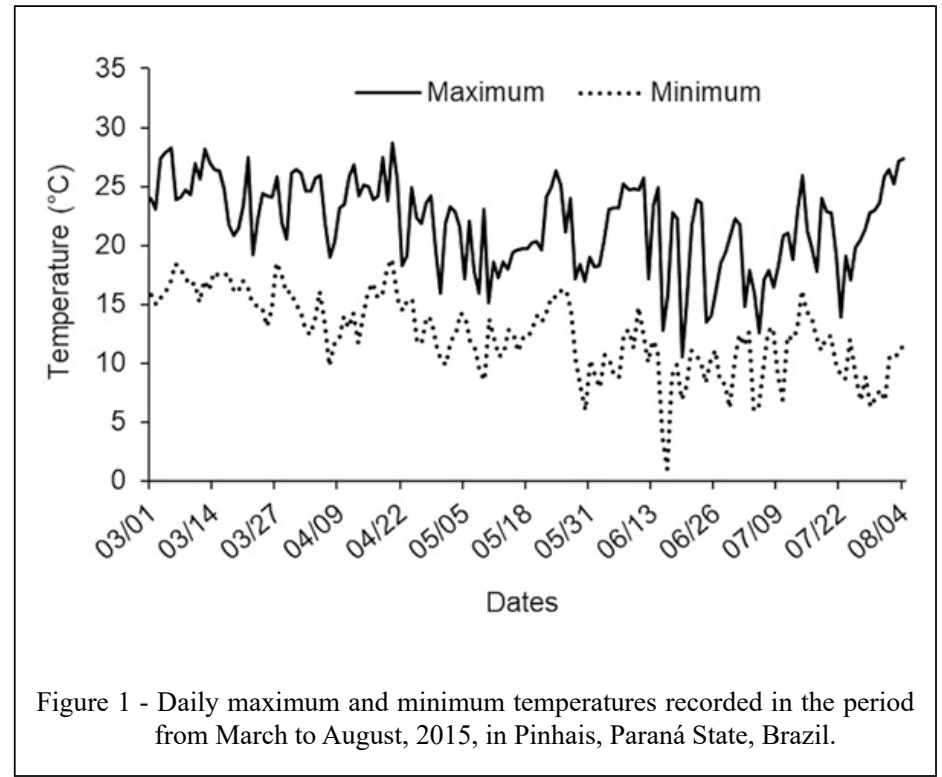

of the already installed endodormancy than the effect of paradormancy, because low budburst ability of the buds under conditions favorable for growth was observed.

ABT decreased to 26.75 days as of $07 / 21$, when the highest FBR of $72.50 \%$ was obtained. On 08/04, the buds presented the lowest ABT of 19.38 days, indicating that the plant was more suitable for budburst or had a lower intensity of dormancy, since values of ABT below 14 days and a FBR above $90 \%$ are considered indicative of the absence of dormancy in 'Fuyu' persimmon tree (CARVALHO et al., 2010a).
In April, when there was no stimulation of low temperatures to decrease metabolism, the plants were already dormant. This dynamic may be related to the effect of the photoperiod, the decrease of which in this period may have contributed to the establishment of dormancy.

The environmental conditions with chilling hours below $7.2^{\circ} \mathrm{C}$, considered insufficient for the Fuyu cultivar, were not limiting for the induction of natural dormancy overcoming. In the region of Campina Grande do Sul, $553 \mathrm{CH}$ below $12{ }^{\circ} \mathrm{C}$ occurred (Table 1), which together with the increase in photoperiod, may have stimulated the release of persimmon bud dormancy.

Table 1 - Chilling hours $\leq 7.2^{\circ} \mathrm{C}$ and $\leq 12{ }^{\circ} \mathrm{C}$ recorded in the period from March to August, 2015, in Pinhais, Paraná State, Brazil.

\begin{tabular}{|c|c|c|c|c|}
\hline \multirow{2}{*}{$\begin{array}{l}\text { Periods } \\
2015\end{array}$} & \multicolumn{2}{|c|}{ 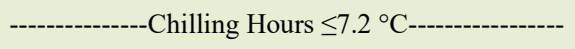 } & \multicolumn{2}{|c|}{ 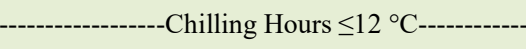 } \\
\hline & Between dates & Accumulated & Between dates & Accumulated \\
\hline $03 / 31$ to $03 / 31$ & 0 & 0 & 0 & 0 \\
\hline $04 / 01$ to $04 / 14$ & 0 & 0 & 4 & 4 \\
\hline $04 / 15$ to $04 / 28$ & 0 & 0 & 0 & 4 \\
\hline $04 / 29$ to $05 / 12$ & 0 & 0 & 43 & 47 \\
\hline $05 / 13$ to $05 / 26$ & 0 & 0 & 13 & 60 \\
\hline $05 / 27$ to $06 / 09$ & 3 & 3 & 98 & 158 \\
\hline $06 / 10$ to $06 / 23$ & 15 & 18 & 124 & 282 \\
\hline $06 / 24$ to $07 / 07$ & 6 & 24 & 136 & 418 \\
\hline $07 / 08$ to $07 / 21$ & 0 & 24 & 20 & 438 \\
\hline $07 / 22$ to $08 / 04$ & 3 & 27 & 115 & 553 \\
\hline
\end{tabular}




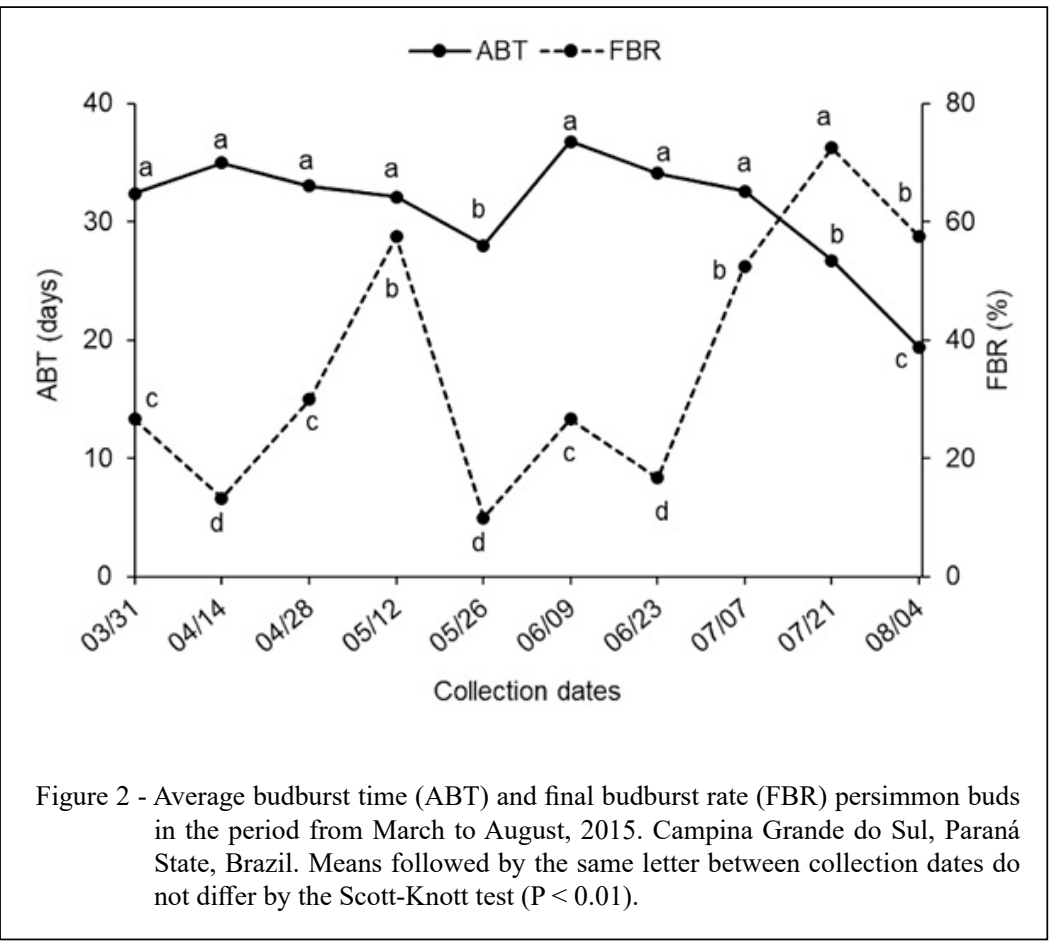

\section{Water content of buds}

At the beginning of the collection of the branches, the buds had a low water content of 0.69 on 03/31 (Figure 3), which it may have occurred due to the influence of the still-engaged paradormancy. The leaves and fruits present compete with buds during the distribution of photoassimilates, and greater transport of water to these structures may have occurred, to

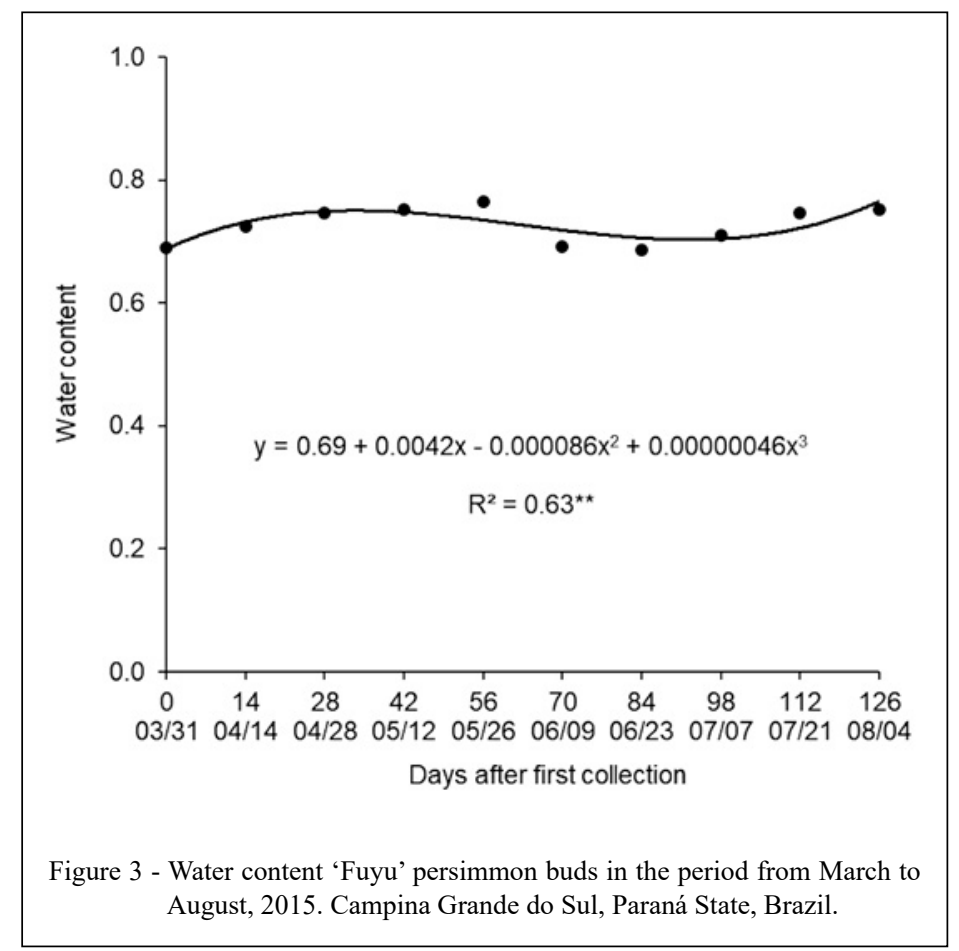

Ciência Rural, v.52, n.1, 2022. 
the detriment of the buds (LEMOINE et al., 2013; ZANON et al., 2015).

With the fall of the leaves and the harvest of the fruits until the end of April, an increase in the water content of the buds of up to 0.77 was observed on $05 / 26$. The decrease in the paradormancy effect may have increased the flow of water to the buds due to elimination of the factors that conditioned the inhibition. During this period, the FBR increased from $13.28 \%$ on $04 / 14$ to $57.50 \%$ on $05 / 12$ (Figure 2), which it may have occurred due to the higher hydration of the buds and changes in the physical state of the membranes (YOOYONGWECH et al., 2008). However, the increase in budburst was not accompanied by a decrease in the ABT. The higher water content in the buds and the higher FBR did not overcome dormancy because this is a transitional period for endodormancy, which associated with temperature fluctuations (Figure 1), may have induced changes in plant metabolism.

From $06 / 09$, the water content decreased to 0.69 and remained low until $06 / 23$, this decrease in water content occurred at the time that the plant began to accumulate $\mathrm{CH}$ in the field below $7.2^{\circ} \mathrm{C}$ and higher values of $\mathrm{CH}$ below $12{ }^{\circ} \mathrm{C}$ between collection dates (Table 1). The cold may have intensified endodormancy, as the FBR decreased and resistance strategies such as water migration from the buds to the branches may have been established (ARORA et al., 2003; YOOYONGWECH et al., 2008). MARAFON et al. (2011) reported a decrease in the water content of pear tree buds during dormancy and an increase in water content in adjacent tissues such as branches, which they are less sensitive to low temperatures.

The decrease in the water content in the meristematic tissues increases the concentration of solutes and decreases the freezing point of the cells, mechanisms that prevent the formation of ice crystals and the rupture of the cells to allow greater resistance of these structures to cold (ARORA et al., 2003).

The water content of buds increased from $07 / 07$, with a value of 0.75 in the last collection of branches on $08 / 04$. In the same period, the budburst capacity increased to $72.50 \%$ after accumulation of $438 \mathrm{CH}$ below $12{ }^{\circ} \mathrm{C}$, indicating a lower intensity of endodormancy at this time. The higher water content in the buds may have provided hydrolysis of stored macromolecules and increased plant metabolism for budburst. Water transport is facilitated in plant cells by aquaporins, integral membrane proteins that form water-selective channels in membranes (JOHANSSON et al., 2000), and they are involved in nutrient transport, cell signaling, and stress responses to low temperatures that occur during the dormancy period (ARORA et al., 2003). In peach, an increase in aquaporin transcription is related to the release of endodormancy and increase in the water content of buds (YOOYONGWECH et al., 2008).

The dynamic of water is important in temperate fruit during the period of dormancy and induction of budburst, as it acts in the processes of mobilization of carbohydrates and activation of metabolism. BONHOMME et al. (2005) verified that sucrose and sorbitol contents in peach flower buds increased after the release of dormancy, but with lower concentrations, which may have occurred due to the higher flow of water in the buds.

\section{Reducing sugar content}

During dormancy, the concentration of reserve carbohydrates varies in the plant and it is able to increase or decrease depending on the species or cultivar in response to low temperatures and a short photoperiod (TANINO et al., 2010). Reserve carbohydrates generally included soluble and insoluble substances, such as soluble sugars and starch, respectively. The increase in the reducing sugar content, such as the glucose and fructose hexoses, which are soluble sugars of low mobility in the phloem because of their reducing property, play an important role in the release of bud dormancy (MAUREL et al., 2004).

Significant variations were observed in the content of reducing sugars between the dates of collection of branches. The lower contents of reducing sugars were obtained between $03 / 31$ and $05 / 26$ (Figure 4), when the plant was in the transition from paradormancy to endodormancy, with decreased metabolism and inhibition of budburst.

The reducing sugars content increased from $05 / 26$, when the plants had accumulated 60 $\mathrm{CH}$ below $12{ }^{\circ} \mathrm{C}$. With the entry into dormancy and with cold treatment, there was a decrease in the concentration of starch and nonreducing sugars and an increase in the concentration of reducing sugars as a form of resistance to cold. Pear buds subjected to low temperatures also display an increase in reducing sugars (MARAFON et al., 2011).

In the collection carried out on $07 / 21$, the buds had the highest reducing sugar content, which coincided with the increase in FBR, decrease in ABT (Figure 2) and increase in water content (Figure 3). On 08/04, a decrease in reducing sugars was observed, which may have occurred due to the increase in the metabolic activity of the buds and consumption of the reducing sugars during respiration to produce energy for budburst. 


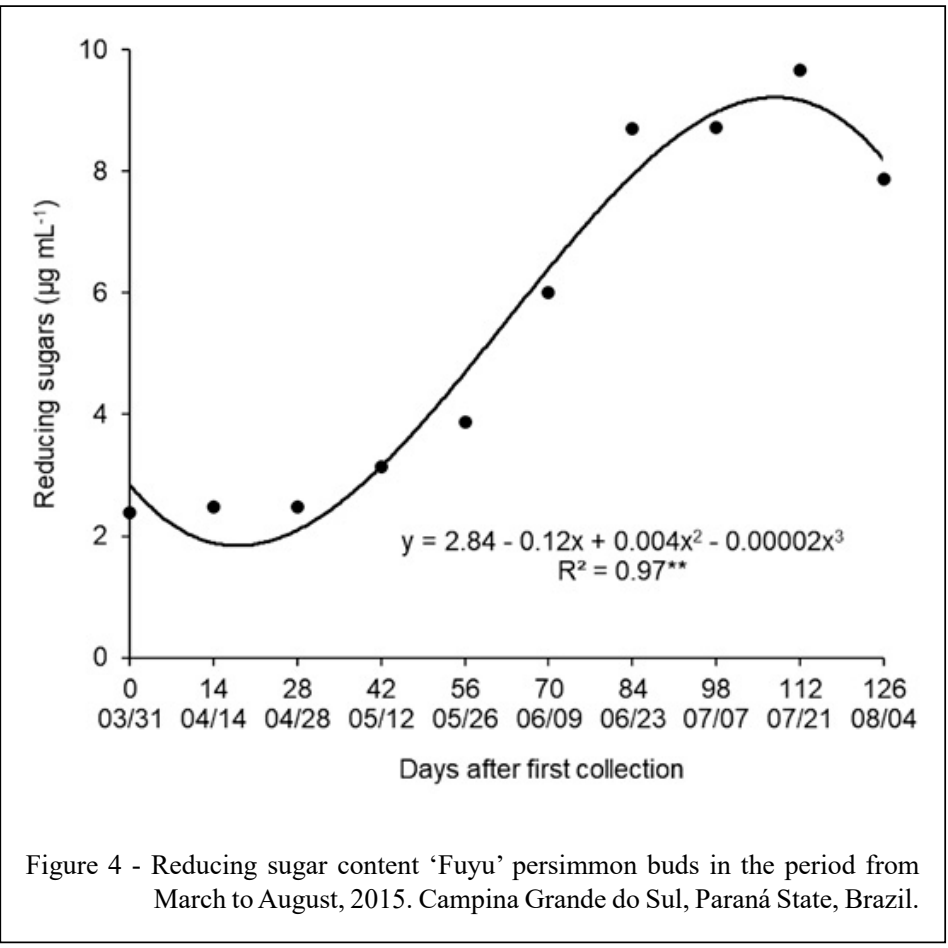

Some species, such as apple, peach, nectarine, plum and apricot, present a decrease in the total soluble sugar content and an increase in reducing sugars in buds during dormancy (BONHOMME et al., 2005). In kiwifruit and pear, starch hydrolysis and an increase in the concentration of reducing and nonreducing sugars in buds in the period of dormancy occur, with a decrease in reducing nonreducing sugars and an increase in reducing sugars before budburst (RICHARDSON et al., 2010; MARAFON et al., 2011; COOKE et al., 2012).

\section{Respiratory activity of buds}

Respiratory activity is essential for the maintenance of metabolism, which continues to occur during dormancy, although to a lesser extent (LI et al., 2011). At the beginning of the collection of the branches, on 03/31, the buds had the highest respiratory activity in the studied period (Figure 5). At this time, the limitation of budburst was already established, with a high ABT and a low FBR (Figure 2), and the high respiratory activity may have occurred more in response to paradormancy than to the induction of endodormancy, because the buds still had high metabolic activity.

Respiratory activity decreased from 4/14 to $05 / 12$, the period in which temperature decreased
(Figure 1), with the onset of $\mathrm{CH}$ accumulation below $12{ }^{\circ} \mathrm{C}$ (Table 1) and a decrease in the photoperiod, which it induces a decrease in plant metabolism and entry into endodormancy (LI et al., 2011).

The respiratory rate remained low between 05/12 and 07/21, when the lowest absorbance values were obtained and possible induction of endodormancy was observed. According to CARVALHO et al. (2010a) endodormancy in persimmon tree begins from the middle of May to the beginning of June, in warm regions. These changes in respiratory activity during dormancy were also observed in vines (PÉREZ et al., 2008) and nectarines (TAN et al., 2010; LI et al., 2011).

Nectarine bud dormancy is caused by a decreased photoperiod, which induces the transition from the respiratory pathways of glycolysis and tricarboxylic acid to the phosphate pentoses pathway (LI et al., 2011). After enough cold accumulation, there is a decrease in the phosphate pentose pathway and an activation of the glycolysis and tricarboxylic acid pathways, which characterize dormancy overcoming (TAN et al., 2010).

In the last collection, performed on 08/04, the buds exhibited increased respiratory activity. This behavior indicated that in the period of endodormancy, the buds presented a decrease in the metabolic activity and that after the accumulation of $553 \mathrm{CH}$ below $12^{\circ} \mathrm{C}$, 


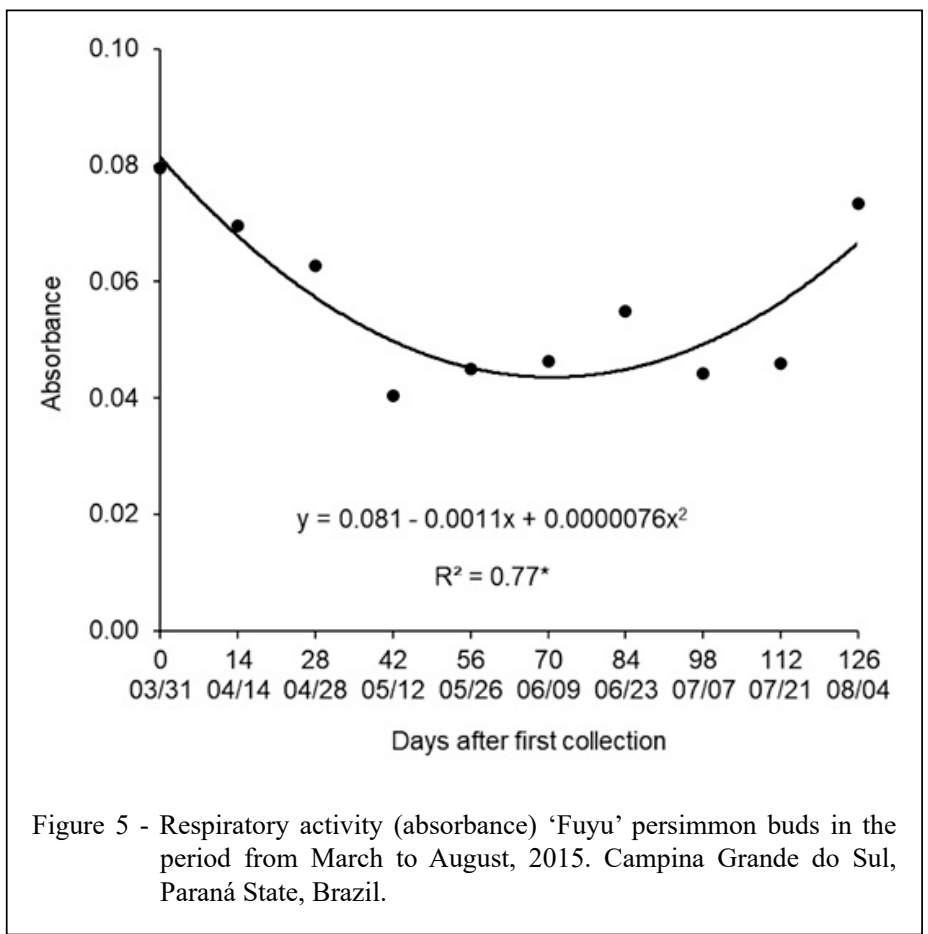

an increase in water content and a high reducing sugar content, the buds resumed metabolic activity and, increased respiratory activity to activate budburst.

\section{Oxidative stress in buds}

$\mathrm{H}_{2} \mathrm{O}_{2}$ is produced in various cellular compartments, and when present at high concentrations, it may be toxic and cause membrane lipid peroxidation, protein oxidation, enzyme inhibition and damage to DNA and RNA. The main enzyme that degrades $\mathrm{H}_{2} \mathrm{O}_{2}$ is catalase (CAT), also called hydroperoxidase, which converts $\mathrm{H}_{2} \mathrm{O}_{2}$ to water and oxygen. Guaiacol (POD) and ascorbate (APX) peroxidases also degrade $\mathrm{H}_{2} \mathrm{O}_{2}$ (BEAUVIEUX et al., 2018).

The activity of SOD, CAT, POD and APX enzymes decreased during the evaluated period (Figures 6A, B, C, D). The enzymes CAT and POD showed low activity after $06 / 09$, when the plants started accumulating cold hours below $7.2^{\circ} \mathrm{C}$ and they were induced to endodormancy (Table 1). Conditions of low winter temperatures decreased the activity of these antioxidant enzymes with an increasing amount of ROS in lemon (KASRAOUI et al., 2014).

The accumulation of ROS can pose a threat to cells but is also involved in the signal transduction pathway to release dormancy. The process by which $\mathrm{H}_{2} \mathrm{O}_{2}$ induced budburst, and the favorable and toxic concentrations for the plants are still unclear, but the role of ROS metabolism in overcoming bud dormancy was discussed, as the release of endodormancy, and budburst coincided with the period of $\mathrm{H}_{2} \mathrm{O}_{2}$ content increase in buds (BEAUVIEUX et al., 2018).

The decrease in the activity of the antioxidant enzymes SOD, CAT, POD and APX was accompanied by an increase in $\mathrm{H}_{2} \mathrm{O}_{2}$ content (Figure $6 \mathrm{~F}$ ). It is possible to observe that the induction of dormancy release, accompanied by a decrease in the $\mathrm{ABT}$ and an increase in the FBR on 07/21 and 08/04, occurred when $\mathrm{H}_{2} \mathrm{O}_{2}$ levels were higher, suggesting the possible involvement of this molecule in bud dormancy release in persimmon.

In subtropical regions with higher temperatures during winter, the bud break occurs unevenly and it causes a decrease in fruit production. The low accumulation of cold in these regions can inhibit the functioning of the oxidative system, making the use of plant regulators to stimulate and to standardize budburst necessary. The main product used is hydrogenated cyanamide, which inhibits the activity of antioxidant enzymes; and consequently, the $\mathrm{H}_{2} \mathrm{O}_{2}$ content increases, guaranteeing bud break (SUDAWAN et al., 2016).

The PPO activity decreased from $03 / 31$ to 08/04 (Figure 6E) and suggested an increase in the phenolic compound content of buds in the period of 


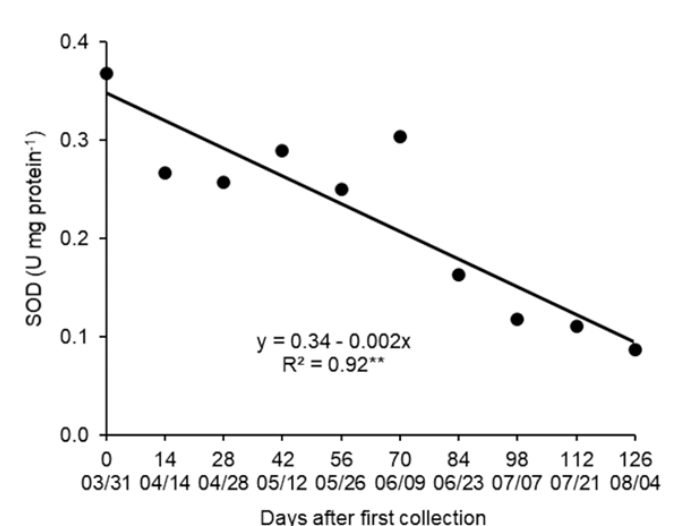

(A)

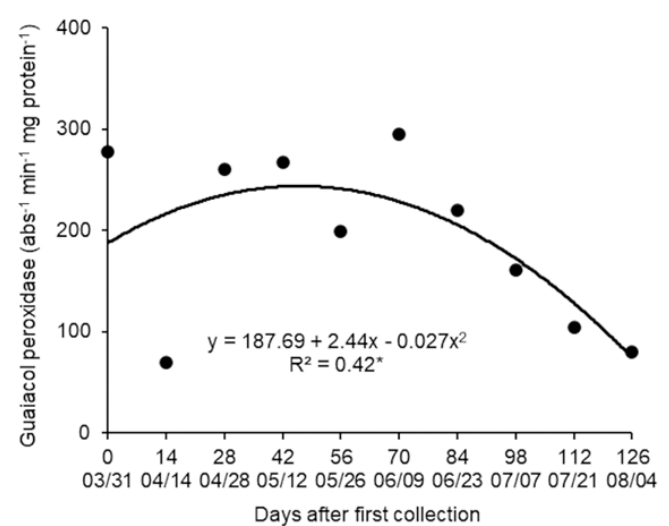

(C)

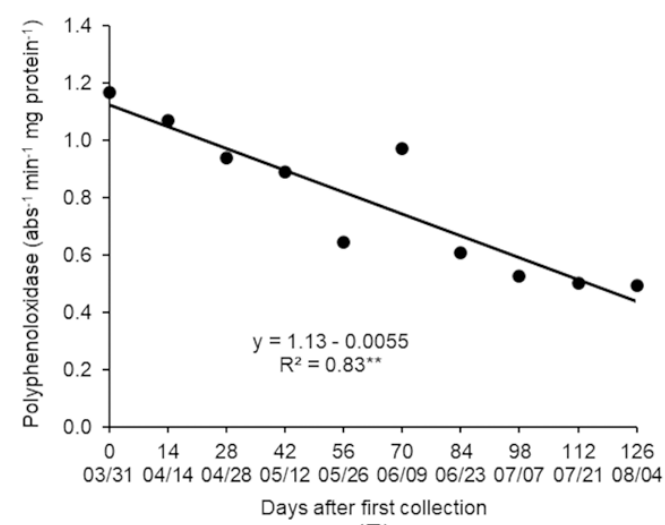

(E)

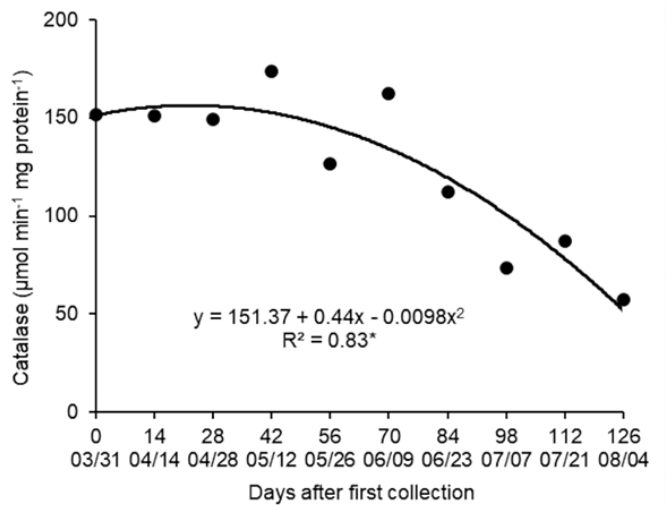

(B)

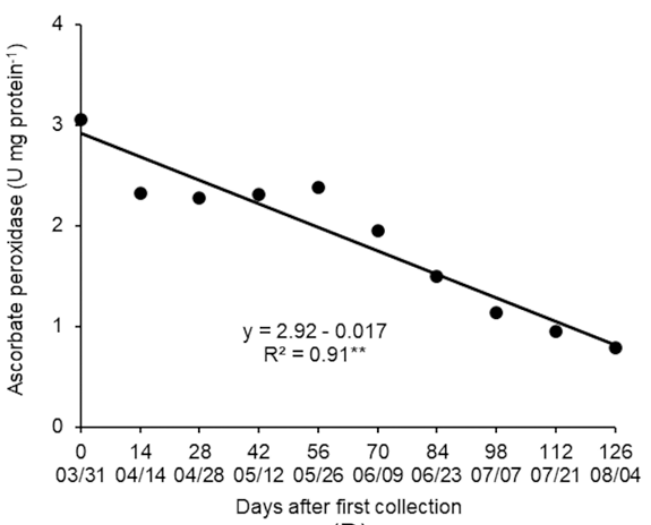

(D)

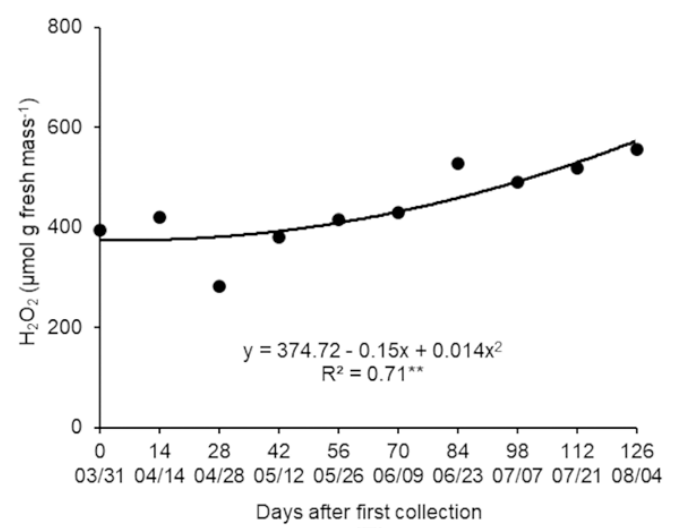

(F)

Figure 6 - Superoxide dismutase (SOD) (A), catalase (B), guaiacol peroxidase (C), ascorbate peroxidase (D) and polyphenol oxidase (E) enzymes activity and hydrogen peroxide content $(\mathrm{F})$ 'Fuyu' persimmon buds in the period from March to August, 2015. Campina Grande do Sul, Paraná State, Brazil.

dormancy. It may be that the phenolic compounds at greater quantity have contributed to the levels of ROS did not reach toxic levels, and consequently, the increase in the $\mathrm{H}_{2} \mathrm{O}_{2}$ contents could have occurred only until concentrations were favorable to dormancy overcoming without causing damage to the plant.

Lipid peroxidation is the process in which ROS oxidize the unsaturated fatty acids of plasma cell 
membranes and form lipid hydroperoxides, which decrease fluidity and modify the ionic permeability of membranes, causing interference in protein functions, reduction of energy supply, accentuated release of ions and decreased selectivity for entry or exit of nutrients and toxic substances to the cell (MA et al., 2013).

The lipid peroxidation values fluctuated during the study period(Figure 7), but without a definite trend in relation to the dormancy phases and without correlation with the other analyzed variables (Table 2), which it suggested that in persimmon buds, lipid peroxidation may not be related to the dynamics of dormancy.

No information has been reported regarding the involvement of lipid peroxidation during bud dormancy in other species. However, WANG \& JIAO (2001) verified that lipid peroxidation in blackberry occurred in response to the increase in $\mathrm{H}_{2} \mathrm{O}_{2}$ levels and a decrease in CAT, SOD, POD and APX activity.

There was a negative correlation between SOD, CAT, APX and PPO enzyme activity and the $\mathrm{CH}$ values below or equal to $7.2{ }^{\circ} \mathrm{C}$ and $12{ }^{\circ} \mathrm{C}$ (Table 2), confirming the effect of cold accumulation on the decrease in the activity of these antioxidant enzymes. The $\mathrm{H}_{2} \mathrm{O}_{2}$ contents presented a positive correlation with $\mathrm{CH}$ accumulation below or equal to $7.2{ }^{\circ} \mathrm{C}$ and $12{ }^{\circ} \mathrm{C}$ and a negative correlation with
SOD, CAT, APX and PPO enzyme activity (Table 2); the higher the accumulation of cold, the lower the activity of antioxidant enzymes and the higher the accumulation of $\mathrm{H}_{2} \mathrm{O}_{2}$ in persimmon buds.

The accumulation of cold also influenced the increase in reducing sugar content, with a positive correlation between $\mathrm{CH}$ and reducing sugars (Table 2). In conditions of low temperatures, the content of reducing sugars in persimmon buds increases, which can occur as a form of protection against the freezing of the bud tissues; therefore, the correlation between reducing sugars and minimum daily temperatures was negative (Table 2).

The correlation analysis between chilling hours below $7.2^{\circ} \mathrm{C}$ and $12^{\circ} \mathrm{C}$ presented similar results for the other analyzed variables (Table 2 ), confirming that temperatures below $12{ }^{\circ} \mathrm{C}$ presented the same cold effect to overcome bud dormancy of persimmon as temperatures below $7.2{ }^{\circ} \mathrm{C}$. Thermal fluctuations during autumn and winter influence the dynamics of dormancy, since respiratory activity showed a positive correlation with maximum temperatures; the higher the temperature during dormancy, the higher the respiratory rate of the buds (Table 2).

'Fuyu'persimmon buds showed a dormancy dynamic similar to that observed for other species of

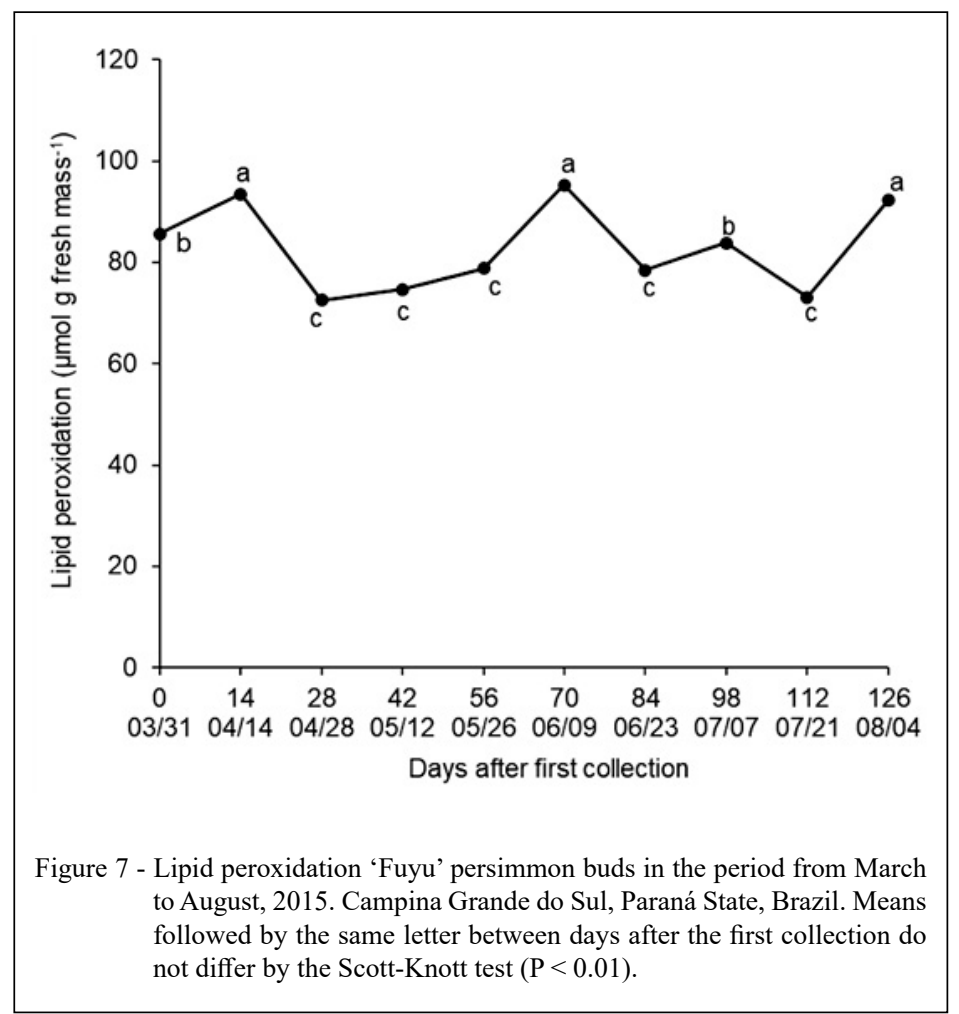

Ciência Rural, v.52, n.1, 2022. 
Table 2 - Pearson's correlation coefficients for daily maximum (T. MAX.) and minimum (T. MIN.) temperature between collection dates, chilling hours $(\mathrm{CH}) \leq 7.2{ }^{\circ} \mathrm{C}$ and $\leq 12{ }^{\circ} \mathrm{C}$ accumulated, average budburst time (ABT), final budburst rate (FBR), water content (WC), reducing sugar content (RS), respiratory activity (RESP), superoxide dismutase (SOD), catalase (CAT), guaiacol peroxidase (POD), ascorbate peroxidase (APX) and polyphenol oxidase (PPO) enzymes activity, hydrogen peroxide content $\left(\mathrm{H}_{2} \mathrm{O}_{2}\right)$ and lipid peroxidation (LP) 'Fuyu' persimmon buds in the period from March to August, 2015. Campina Grande do Sul, Paraná State, Brazil.

\begin{tabular}{|c|c|c|c|c|c|c|c|c|c|c|c|c|}
\hline & $\mathrm{ABT}$ & FBR & WC & $\mathrm{RS}$ & RESP & SOD & CAT & POD & APX & PPO & $\mathrm{H}_{2} \mathrm{O}_{2}$ & LP \\
\hline T. MAX. & $-0.03^{\mathrm{ns}}$ & $-0.42^{\mathrm{ns}}$ & $0.10^{\mathrm{ns}}$ & $-0.59^{\mathrm{ns}}$ & $0.77^{* *}$ & $0.43^{\mathrm{ns}}$ & $0.34^{\mathrm{ns}}$ & $-0.08^{\mathrm{ns}}$ & $0.46^{\mathrm{ns}}$ & $0.58^{\mathrm{ns}}$ & $-0.40^{\mathrm{ns}}$ & $0.24^{\mathrm{ns}}$ \\
\hline T. MIN. & $0.20^{\mathrm{ns}}$ & $-0.34^{\mathrm{ns}}$ & $0.20^{\mathrm{ns}}$ & $-0.77^{* *}$ & $0.36^{\mathrm{ns}}$ & $0.66^{*}$ & $0.54^{\mathrm{ns}}$ & $0.28^{\mathrm{ns}}$ & $0.78^{* *}$ & $0.64^{*}$ & $-0.76^{* *}$ & $-0.30^{\mathrm{ns}}$ \\
\hline $\mathrm{CH} \leq 7.2^{\circ} \mathrm{C}$ & $-0.56^{\mathrm{ns}}$ & $0.61^{\mathrm{ns}}$ & $-0.03^{\mathrm{ns}}$ & $0.92^{* *}$ & $-0.08^{\mathrm{ns}}$ & $-0.93^{* *}$ & $-0.93^{* *}$ & $-0.56^{\mathrm{ns}}$ & $-0.94^{* *}$ & $-0.84^{* *}$ & $0.86^{* *}$ & $0.01^{\mathrm{ns}}$ \\
\hline $\mathrm{CH} \leq 12{ }^{\circ} \mathrm{C}$ & $-0.62^{\mathrm{ns}}$ & $0.64^{*}$ & $0.02^{\mathrm{ns}}$ & $0.92^{* *}$ & $-0.12^{\mathrm{ns}}$ & $-0.91 * *$ & $-0.92^{* *}$ & $-0.55^{\mathrm{ns}}$ & $-0.96^{* *}$ & $-0.85^{* *}$ & $0.86^{* *}$ & $0.09^{\mathrm{ns}}$ \\
\hline $\mathrm{ABT}$ & & $-0.51^{\mathrm{ns}}$ & $-0.59^{\mathrm{ns}}$ & $-0.35^{\mathrm{ns}}$ & $-0.19^{\mathrm{ns}}$ & $0.60^{\mathrm{ns}}$ & $0.70^{*}$ & $0.55^{\mathrm{ns}}$ & $0.53^{\mathrm{ns}}$ & $0.62^{\mathrm{ns}}$ & $-0.49^{\mathrm{ns}}$ & $0.05^{\mathrm{ns}}$ \\
\hline FBR & & & $0.27^{\mathrm{ns}}$ & $0.51^{\mathrm{ns}}$ & $-0.25^{\mathrm{ns}}$ & $-0.54^{\mathrm{ns}}$ & $-0.48^{\mathrm{ns}}$ & $-0.27^{\mathrm{ns}}$ & $-0.62^{\mathrm{ns}}$ & $-0.48^{\mathrm{ns}}$ & $0.35^{\mathrm{ns}}$ & $-0.26^{\mathrm{ns}}$ \\
\hline WC & & & & $-0.16^{\mathrm{ns}}$ & $-0.19^{\mathrm{ns}}$ & $-0.25^{\mathrm{ns}}$ & $-0.15^{\mathrm{ns}}$ & $-0.38^{\mathrm{ns}}$ & $-0.12^{\mathrm{ns}}$ & $-0.32^{\mathrm{ns}}$ & $-0.17^{\mathrm{ns}}$ & $-0.42^{\mathrm{ns}}$ \\
\hline RS & & & & & $-0.34^{\mathrm{ns}}$ & $-0.85^{* *}$ & $-0.80^{* *}$ & $-0.38^{\mathrm{ns}}$ & $-0.91^{* *}$ & $-0.84^{* *}$ & $0.86^{* *}$ & $-0.03^{\mathrm{ns}}$ \\
\hline RESP & & & & & & $0.18^{\mathrm{ns}}$ & $-0.03^{\mathrm{ns}}$ & $-0.20^{\mathrm{ns}}$ & $0.24^{\mathrm{ns}}$ & $0.41^{\mathrm{ns}}$ & $-0.05^{\mathrm{ns}}$ & $0.41^{\mathrm{ns}}$ \\
\hline SOD & & & & & & & $0.92^{* *}$ & $0.68^{*}$ & $0.95^{* *}$ & $0.92^{* *}$ & $-0.75^{*}$ & $0.12^{\mathrm{ns}}$ \\
\hline CAT & & & & & & & & $0.66^{*}$ & $0.86^{* *}$ & $0.86^{* *}$ & $-0.78^{* *}$ & $-0.03^{n s}$ \\
\hline POD & & & & & & & & & $0.59^{\mathrm{ns}}$ & $0.49^{\text {ns }}$ & $-0.58^{\mathrm{ns}}$ & $-0.22^{\mathrm{ns}}$ \\
\hline APX & & & & & & & & & & $0.87^{* *}$ & $-0.79^{* *}$ & $-0.02^{\mathrm{ns}}$ \\
\hline PPO & & & & & & & & & & & $-0.72^{*}$ & $0.26^{\mathrm{ns}}$ \\
\hline $\mathrm{H}_{2} \mathrm{O}_{2}$ & & & & & & & & & & & & $0.28^{\mathrm{ns}}$ \\
\hline
\end{tabular}

* and ${ }^{* *}$ significant at the 5 and $1 \%$ level of probability, respectively.

${ }^{\text {ns }}$ no significant.

temperate climate, overcoming endodormancy after a period of cold accumulation (ARORA et al., 2003), even with mild winter conditions. This response occurred due to the accumulation of cold with temperatures below $12{ }^{\circ} \mathrm{C}$ having the same effect as temperatures below $7.2^{\circ} \mathrm{C}$ (Table 2). Temperatures up to $13{ }^{\circ} \mathrm{C}$ were also effective for the budburst of endodormant apple and pear tree buds (JACOBS et al., 2002). Oriental pear cultivars also showed that temperatures up to $12{ }^{\circ} \mathrm{C}$ were effective for chilling accumulation (PARK \& PARK, 2020). This response allows the persimmon tree to adapt in mild winter climates, as evaluated in this study.

During the dormancy, a variation in carbohydrate metabolism and oxidative stress in the buds was observed, following a pattern of increased reducing sugars and reduction of the main anti-oxidant enzymes, causing an increase in $\mathrm{H}_{2} \mathrm{O}_{2}$ content, which culminates in sprouting of the buds. These results confirm the complexity of the dormancy process, which involves physiological and biochemical changes, with a strong genetic effect, but subject to the effect of environmental conditions, which act in the epigenetic regulation of gene expression (COOKE et al., 2012; FALAVIGNA et al., 2019).

\section{CONCLUSION}

Taken together, our results suggested that persimmon buds in endodormancy, stimulated by the onset of accumulation of chilling hours, present a decrease in water content and respiratory activity, an increase in reducing sugars, a decrease in SOD, CAT, APX and PPO enzyme activity and an increase in $\mathrm{H}_{2} \mathrm{O}_{2}$. When the release of endodormancy begins, the buds present an increase in water content, a decrease in reducing sugar content, an increase in respiratory activity, a low activity of the SOD, CAT, APX and POD enzymes and elevated levels of $\mathrm{H}_{2} \mathrm{O}_{2}$.

\section{ACKNOWLEDGMENTS}

The authors thank the Conselho Nacional de Desenvolvimento Científico e Tecnológico (CNPq) and Coordenação de Aperfeiçoamento de Pessoal de Nível Superior (CAPES - Finance Code 001) for financial support.

\section{DECLARATION OF CONFLICT OF INTEREST}

The authors declare no conflict of interest. The founding sponsors had no role in the design of the study; in the 
collection, analyses, or interpretation of data; in the writing of the manuscript, and in the decision to publish the results.

\section{AUTHORS' CONTRIBUTIONS}

GPP ran the field and laboratory work, processed the data and drafted the paper. FF and AJM collaborated in laboratory work. RVB and RINC contributed to the design of the study. FZ and LAB supervised the research, collaborated in critically reading and the final version of the manuscript.

\section{REFERENCES}

ARORA, R. et al. Induction and release of bud dormancy in woody perennials: a science comes of age. HortScience, v.38, n.5, p.911-921, 2003. Available from: <https://doi.org/10.21273/ HORTSCI.38.5.911>. Accessed: Oct. 21, 2020. doi: 10.21273/ HORTSCI.38.5.911.

BEAUVIEUX, R. et al. Bud dormancy in perennial fruit tree species: a pivotal role for oxidative cues. Frontiers in Plant Science, v.9, article 657, 2018. Available from: <https://doi. org/10.3389/fpls.2018.00657>. Accessed: Oct. 21, 2020. doi: $10.3389 /$ fpls.2018.00657.

BONHOMME, M. et al. Influences of cold deprivation during dormancy on carbohydrate contents of vegetative and floral primordia and nearby structures of peach buds (Prunus persica L. Batch). Scientia Horticulturae, v.105, n.2, p.223-240, 2005. Available from: <https://doi.org/10.1016/j.scienta.2005.01.015>. Accessed: Oct. 21, 2020. doi: 10.1016/j.scienta.2005.01.015.

BRADFORD, M. M. A rapid and sensitive method for the quantitation of microgram quantities of protein utilizing the principle of protein-dye binding. Analytical Biochemistry, v.72, p.248-254, 1976. Available from: <https://doi.org/10.1016/00032697(76)90527-3>. Accessed: Oct. 21, 2020. doi: 10.1016/00032697(76)90527-3.

CARVALHO, R. I. N. et al. Dormancy dynamics of 'Fuyu' persimmon tree buds in a region of low chill occurrence. Scientia Agraria, v.11, n.1, p.57-63, 2010a. Available from: $<$ https://revistas. ufpr.br/agraria/article/view/16077/10975>. Accessed: Oct. 21, 2020.

CARVALHO, R. I. N. et al. Metabolic activity evaluation of temperate tree fruit buds by using the tetrazolium test. Acta Horticulturae, n.872, p.89-96, 2010b. Available from: <https:// doi.org/10.17660/ActaHortic.2010.872.9>. Accessed: Oct. 21, 2020. doi: 10.17660/ActaHortic.2010.872.9.

COOKE, J. E. K. et al. The dynamic nature of bud dormancy in trees: environmental control and molecular mechanisms. Plant, Cell \& Environment, v.35, n.10, p.1707-1728, 2012. Available from: $\quad<$ https://doi.org/10.1111/j.1365-3040.2012.02552.x> Accessed: Oct. 21, 2020. doi: 10.1111/j.1365-3040.2012.02552.x.

DUANGMAL, K.; APENTEN, R. K. O. A comparative study of polyphenoloxidases from taro (Colocasia esculenta) and potato (Solanun tuberosum var. Romano). Food Chemistry, v.64, n.3, p.351-359, 1999. Available from: <https://doi.org/10.1016/S03088146(98)00127-7>. Accessed: Oct. 21, 2020. doi: 10.1016/S03088146(98)00127-7.

EL YAACOUBI, A. et al. Differentiated dynamics of bud dormancy and growth in temperate fruit trees relating to bud phenology adaptation, the case of apple and almond trees. International Journal of Biometeorology, v.60, n.11, p.1695-1710, 2016. Available from: <https://doi.org/10.1007/s00484-016-1160-9>. Accessed: Oct. 21, 2020. doi: 10.1007/s00484-016-1160-9.

FALAVIGNA, V. S. et al. I want to (bud) break free: the potential role of DAM and SVP-Like genes in regulating dormancy cycle in temperate fruit trees. Frontiers in Plant Science, v.9, article 1990, 2019. Available from: $<$ https://doi.org/10.3389/fpls.2018.01990>. Accessed: Oct. 21, 2020. doi: 10.3389/fpls.2018.01990.

FAQUIM, R. et al. Necessidade de frio para quebra de dormência de gemas de caquizeiro 'Fuyu'. Revista Brasileira de Fruticultura, v.29, n.3, p.438-444, 2007. Available from: <https:// doi.org/10.1590/S0100-29452007000300007>. Accessed: Oct. 21, 2020. doi: 10.1590/S0100-29452007000300007.

GARCÍA-CARBONELL, S. et al. Phenological growth stages of the persimmon tree (Diospyros kaki). Annals of Applied Biology, v.141, n.1, p.73-76, 2002. Available from: $<$ https://doi. org/10.1111/j.1744-7348.2002.tb00197.x>. Accessed: Jan. 13, 2021. doi: 10.1111/j.1744-7348.2002.tb00197.x.

GIANNOPOLITIS, C. N.; RIES, S. K. Superoxide dismutase. I. Occurrence in higher plants. Plant Physiology, v.59, n.2, p.309314, 1977. Available from: <https://doi.org/10.1104/pp.59.2.309>. Accessed: Oct. 21, 2020. doi: 10.1104/pp.59.2.309.

GÓTH, L. A simple method for determination of serum catalase activity and revision of reference range. Clinica Chimica Acta, v.196, n.2-3, p.143-151, 1991. Available from: <https://doi. org/10.1016/0009-8981(91)90067-M>. Accessed: Oct. 21, 2020. doi: 10.1016/0009-8981(91)90067-M.

GUAN, C. et al. Genetic diversity, germplasm identification and population structure of Diospyros kaki Thunb. from different geographic regions in China using SSR markers. Scientia Horticulturae, v.251, p.233-240, 2019. Available from: <https:// doi.org/10.1016/j.scienta.2019.02.062>. Accessed: Oct. 21, 2020. doi: 10.1016/j.scienta.2019.02.062.

JACOBS, J. N. et al. Chilling period influences the progression of bud dormancy more than does chilling temperature in apple and pear shoots. Journal of Horticultural Science and Biotechnology, v.77, n.3, p.333-339, 2002. Available from: <https://doi.org/10.1 080/14620316.2002.11511502>. Accessed: Jan. 13, 2021. doi: 10.1080/14620316.2002.11511502.

JOHANSSON, I. et al. The role of aquaporins in cellular and whole plant water balance. Biochimica et Biophysica Acta (BBA) - Biomembranes, v.1465, n.1-2, p.324-342, 2000. Available from: $<$ https://doi.org/10.1016/S0005-2736(00)00147-4>. Accessed: Oct. 21, 2020. doi: 10.1016/S0005-2736(00)00147-4.

KAR, M.; MISHRA, D. Catalase, peroxidase, and polyphenoloxidase activities during rice leaf senescence. Plant Physiology, v.57, p.315-319, 1976. Available from: <https://doi. org/10.1104/pp.57.2.315>. Accessed: Oct. 21, 2020. doi: 10.1104/ pp.57.2.315.

KASRAOUI, F. et al. Activities of peroxidase (soluble and cell wall bound) and of other $\mathrm{H}_{2} \mathrm{O}_{2}$ scavenging enzymes are markers of the flower bud development stage in lemon. Journal of Applied Botany and Food Quality, v.87, p.1-8, 2014. Available from: $<$ https://doi.org/10.5073/JABFQ.2014.087.001>. Accessed: Oct. 21, 2020. doi: 10.5073/JABFQ.2014.087.001.

Ciência Rural, v.52, n.1, 2022. 
LEMOINE, R. et al. Source-to-sink transport of sugar and regulation by environmental factors. Frontiers in Plant Science, v.4, p.1-21, 2013. Available from: <https://doi.org/10.3389/fpls.2013.00272>. Accessed: Oct. 21, 2020. doi: 10.3389/fpls.2013.00272.

LEVER, M. A new reaction for colorimetric determination of carbohydrates. Analytical Biochemistry, v.47, n.1, p.273279, 1972. Available from: <https://doi.org/10.1016/00032697(72)90301-6>. Accessed: Oct. 21, 2020. doi: 10.1016/00032697(72)90301-6.

LI, D. et al. Effect of photoperiod on key enzyme activities of respiration in nectarine buds during dormancy induction. Agricultural Sciences in China, v.10, n.7, p.1026-1031, 2011. Available from: <https://doi.org/10.1016/S1671-2927(11)60090-4>. Accessed: Oct. 21, 2020. doi: 10.1016/S1671-2927(11)60090-4.

LORETO, F.; VELIKOVA, V. Isoprene produced by leaves protects the photosynthetic apparatus against ozone damage, quenches ozone products, and reduces lipid peroxidation of cellular membranes. Plant Physiology, v.127, n.4, p.1781-1787. 2001. Available from: <https://doi.org/10.1104/pp.010497>. Accessed: Oct. 21, 2020. doi: 10.1104/pp.010497.

LUSSO, M. F. G.; PASCHOLATI, S. F. Activity and isoenzymatic pattern of soluble peroxidases in maize tissues after mechanical injury or fungal inoculation. Summa Phytopathologica, v.25, n.3, p.244-249, 1999.

MA, H. et al. Mitochondrial response in the apical and lateral flower buds of the Hanfu apple to cold stress during the dormancy stage. Acta Ecologica Sinica, v.33, n.1, p.52-58, 2013. Available from: <https://doi.org/10.1016/j.chnaes.2012.11.002>. Accessed: Oct. 21, 2020. doi: 10.1016/j.chnaes.2012.11.002.

MARAFON, A. et al., Umidade ponderal em tecidos de pereira durante o período de dormência sob condições de inverno ameno. Pesquisa Agropecuária Brasileira, v.46, n.9, p.10061012, 2011. Available from: <http://dx.doi.org/10.1590/S0100204X2011000900006>. Accessed: Oct. 21, 2020. doi: 10.1590/ S0100-204X2011000900006.

MAUREL, K. et al. Trophic control of bud break in peach (Prunus persica) trees: a possible role of hexoses. Tree Physiology, v.24, n.5, p.579-588, 2004. Available from: <https://oi.org/10.1093/ treephys/24.5.579>. Accessed: Oct. 21, 2020. doi: 10.1093/ treephys/24.5.579.

NAKANO, Y.; ASADA, K. Hydrogen peroxide is scavenged by ascorbate specific peroxidase in spinach chloroplasts. Plant and Cell Physiology, v.22, p.867-880, 1981. Available from: $<$ https:// doi.org/10.1093/oxfordjournals.pcp.a076232>. Accessed: Oct. 21, 2020. doi: 10.1093/oxfordjournals.pcp.a076232.

PARK, Y.; PARK, HS. Development of a model to estimate the chilling requirement of oriental pear by standardizing dormancy depth. Horticulture, Environment, and Biotechnology, v.61, n.1, p.11-21, 2020. Available from: <https://doi.org/10.1007/s13580019-00176-y>. Accessed: Jan. 13, 2021. doi: 10.1007/s13580-01900176-y.

PÉREZ, F. J. et al. $\mathrm{H}_{2} \mathrm{O}_{2}$ is involved in the dormancy-breaking effect of hydrogen cyanamide in grapevine buds. Plant Growth Regulation, v.55, n.2, p.149-155, 2008. Available from: <https:// doi.org/10.1007/s10725-008-9269-4>. Accessed: Oct. 21, 2020. doi: 10.1007/s10725-008-9269-4.
RADY, M. M.; EL-YAZAL, M. A. Response of 'Anna' apple dormant buds and carbohydrate metabolism during floral bud break to onion extract. Scientia Horticulturae, v.155, p.78-84, 2013. Available from: <https://doi.org/10.1016/j.scienta.2013.02.025>. Accessed: Oct. 21, 2020. doi: 10.1016/j.scienta.2013.02.025.

RICHARDSON, A. C. et al. Carbohydrate changes in kiwifruit buds during the onset and release from dormancy. Scientia Horticulturae, v.124, n.4, p.463-468, 2010. Available from: $<$ https://doi.org/10.1016/j.scienta.2010.02.010>. Accessed: Oct. 21, 2020. doi: 10.1016/j.scienta.2010.02.010.

SCHMITZ, J. D. et al. Is acrotonic budburst pattern in spring a typical behavior of the low-chilling apple cultivar 'Eva' in mild winter conditions? An approach combining ex planta single-node cutting test and in planta bud water content during dormancy. Scientia Horticulturae, v.188, p.84-88, 2015. Available from: $<$ https://doi.org/10.1016/j.scienta.2015.03.024>. Accessed: Oct. 21, 2020. doi: 10.1016/j.scienta.2015.03.024.

SUDAWAN, B. et al. Hydrogen cyanamide breaks grapevine bud dormancy in the summer through transient activation of gene expression and accumulation of reactive oxygen and nitrogen species. BMC Plant Biology, v.16, 202, 2016. Available from: $<$ https://doi.org/10.1186/s12870-016-0889-y>. Accessed: Oct. 21, 2020. doi: $10.1186 / \mathrm{s} 12870-016-0889-\mathrm{y}$.

TAN, Y. et al. Respiratory response of dormant nectarine floral buds on chilling deficiency. Agricultural Sciences in China, v.9, n.10, p.1448-1454, 2010. Available from: $<$ https://doi.org/10.1016/ S1671-2927(09)60236-4>. Accessed: Oct. 21, 2020. doi: 10.1016/ S1671-2927(09)60236-4.

TANINO, K. K. et al. Temperature-driven plasticity in growth cessation and dormancy development in deciduous woody plants: a working hypothesis suggesting how molecular and cellular function is affected by temperature during dormancy induction. Plant Molecular Biology, v.73, n.1-2, p.49-65, 2010. Available from: <https://doi.org/10.1007/s11103-010-9610-y>. Accessed: Oct. 21, 2020. doi: 10.1007/s11103-010-9610-y.

TOMÁNKOVÁ, K. et al. Biochemical aspects of reactive oxygen species formation in the interaction between Lycopersicon spp. and Oidium neolycopersici. Physiological and Molecular Plant Pathology, v.68, n.1-3, p.22-32, 2006. Available from: <https:// doi.org/10.1016/j.pmpp.2006.05.005>. Accessed: Oct. 21, 2020. doi: 10.1016/j.pmpp.2006.05.005.

VELIKOVA, V. et al. Oxidative stress and some antioxidant systems in acid rain-treated bean plants: protective role of exogenous polyamines. Plant Science, v.151, n.1, p.59-66, 2000. Available from: $\quad<$ https://doi.org/10.1016/S0168-9452(99)00197-1>. Accessed: Oct. 21, 2020. doi: 10.1016/S0168-9452(99)00197-1.

VERGARA, R. et al. Hypoxia induces $\mathrm{H}_{2} \mathrm{O}_{2}$ production and activates antioxidant defense system in grapevine buds through mediation of $\mathrm{H}_{2} \mathrm{O}_{2}$ and ethylene. Journal of Experimental Botany, v.63, n.11, p.4123-4131, 2012. Available from: <https:// doi.org/10.1093/jxb/ers094>. Accessed: Oct. 21, 2020. doi: $10.1093 / \mathrm{jxb} / \mathrm{ers} 094$.

WANG, S. Y.; JIAO, H. Changes in oxygen-scavenging systems and membrane lipid peroxidation during maturation and ripening in blackberry. Journal of Agricultural and Food Chemistry, v.49, n.3, p.1612-1619, 2001. Available from: <https://doi.org/10.1021/ jf0013757>. Accessed: Oct. 21, 2020. doi: 10.1021/jf0013757. 
YOOYONGWECH, S. et al. Changes in aquaporin gene expression and magnetic resonance imaging of water status in peach tree flower buds during dormancy. Physiologia Plantarum, v.134, n.3, p.522-533, 2008. Available from: <https://doi.org/10. 1111/j.1399-3054.2008.01143.x>. Accessed: Oct. 21, 2020. doi: 10.1111/j.1399-3054.2008.01143.x.

ZANON, L. et al. Sucrose transport and phloem unloading in peach fruit: potential role of two transporters localized in different cell types. Physiologia Plantarum, v.154, n.2, p.179-193, 2015. Available from: <https://doi.org/10.1111/ppl.12304>. Accessed: Oct. 21, 2020. doi: 10.1111/ppl.12304.

ZHENG, C. et al. Abscisic acid (ABA) regulates grape bud dormancy, and dormancy release stimuli may act through modification of ABA metabolism. Journal of Experimental Botany, v.66, n.5, p.15271542, 2015. Available from: < https://doi.org/10.1093/jxb/eru519>. Accessed: Oct. 21, 2020. doi: 10.1093/jxb/eru519. 